\title{
Setlining for European Seabass (Dicentrarchus labrax, Linnaeus, 1758); Technical features and bait preference
}

\author{
Bırakma oltası ille levrek (Dicentrarchus labrax, Linnaeus, 1758) avcılığı; \\ Teknik özellikler ve yem tercihi
}

\author{
Ozan Soykan* • Hasan Tuncay Kınacıgil
}

Ege University, Fisheries Faculty, 35100 Bornova, Izmir - Turkey

*Corresponding author: ozansoykan@hotmail.com

\begin{abstract}
Özet: Bu çalışma 2008 yıııın Haziran ve Eylül ayları arasında bırakma oltası ile levrek avcıı̆ı̆ın teknik özelliklerini belirlemek amacılla Çeşme'de (Orta Ege Denizi) yürütülmüştür. Isparoz (Diplodus annularis), kefal (Mugil cephalus) türleri canlı yem, izmarit (Spicara sp.) ve dikensiz sübye (Sepia elegans) türleri de ölü yem olarak kullanılmış olup toplamda 4 farklı yem ile denemeler gerçekleştirilmiş̧ir. Çalışma boyunca kullanılan oltaların \%19'unda levrek, \%9'unda hedef dışı av yakalandığı, \%27'sinin ise koptuğu tespit edilmiştir. Oltaların \%45'inde ise herhangi bir birey yakalanmamıştır. Yakalanan türlerin toplam ağırlıklarının dağıımında levreğin \%79 ile çoğunluğu oluşturduğu bulunmuştur. Bununla beraber yakalanan levreklerin ağırlık bazında \%70'inin orta Ege Denizi'nde kullanılan bırakma oltası ile levrek avclığındaki en verimli yem olan kefal ile avlandığı tespit edilmiştir.
\end{abstract}

Anahtar kelimeler: Levrek, bırakma oltası, Orta Ege Denizi

Abstract: This study was conducted between June and September of 2008 to determine the technical characteristics of setlining for European seabass in the central Aegean Sea, Çeşme. Experiments were carried out by 4 different baits; Annular sea bream (Diplodus annularis) and flathead grey mullet (Mugil cephalus) were used as the live baits while picarel (Spicara sp.) and elegant cuttlefish (Sepia elegans) were used as the dead baits. During the study it was observed that $19 \%$ of the tackles captured European seabass, $9 \%$ of them captured by-catch species and $27 \%$ of those were detached. Finally $45 \%$ of the tackles didn't catch any individuals. Among the weight based distribution of captured species European seabass composed the majority with $79 \%$. On the other hand it was found that $70 \%$ of the European seabasses were captured with flathead grey mullet as being the most efficient bait for European seabass setlining in the central Aegean Sea.

Keywords: European seabass, setlining, middle Aegean Sea

\section{INTRODUCTION}

Fisheries have been performed for centuries by various fishing methods and hand lining is one of the oldest techniques among those. Nowadays angling is performed for both commercial and recreational purposes. Fishing line is composed of hook, main line and auxiliary material by appropriate design and techniques (Hoşsucu, 2003). Recreational fishery, commonly performed by angling has become an individual sector and showed significant economic growth in the last few years (Dilon, 2004). EAA (2003) reported that within the European Union (EU) there are 2900 companies, manufacturers and wholesalers trading in recreational fishing tackle and representing 60.000 jobs and making an annual turnover of 5.000.000.000 Euros. In addition to this amount generated by these businesses there are also an estimated 25.000.000 recreational fisherman who spend estimated minimum 25.000 .000 .000 Euros per year on equipment, transportation and lodgings in $15 \mathrm{EU}$ countries.

Although angling is a very common fishing technique in coastal regions, there are very few studies regarding to this method. Kaykaç et al. (2003) studied the catch efficiency of straight and kirbed hooks in Izmir Bay, Ünal (2003) analysed the socio-economic patterns of part time small scale fishery in Foça (middle Aegean Sea), Ceyhan and Akyol (2005) reported bluefish angling and the tackles used in this fishery in Marmara region. In addition to this Akyol et al. (2009) studied the inshore fishery as well as the fisheries resources in Marmara Island. Also, effects of different baits on length and condition of fish in the recreational fishery were investigated by Aydın (2011) for İmir Bay. Carps (Cyprinus carpio), trouts (Salmo trutta), mackerels (Scomber spp.), bluefish (Pomatomus saltator), brown meagre (Sciaena umbra), sea bass (Dicentrarchus labrax), bonitos (Sarda sarda), sea breams (Diplodus spp., Sparus aurata), common Pandora (Pagellus erythrinus), bogue (Boops boops), blotched picarel (Spicara maena) and squids (Loligo vulgaris) are known as the main species captured by angling in Turkey. Among those the fishing of European sea bass which is also intensively cultured in Turkey and Europe has been performed commercially and recreationally. 
Dicentrarchus labrax known as European seabass is a member of family Moronidae and has a high commercial value which has been cultured and captured. It spreads through the Eastern Atlantic from Norway to Morocco, the Canary Islands and Senegal, also known from the Mediterranean and Black Sea except from White, Barents, Baltic and Caspian Seas (Kottelat and Freyhof, 2007). It is commonly distributed over sea grass, sand, mud and rocks to depths of $100 \mathrm{~m}$ (Frimodt, 1995). The world aquaculture production is 333.412 tonnes in 2010 (FAO, 2010) and 50.796 tonnes production was performed in Turkey by the same way in 2010 according to TÜIK (2010). Furthermore there has been no data about the capture production of the species for Turkey. The main fishing gears used in seabass capturing are gill nets, longlines, fish weirs, hand lines (angling) and spears. In this study, it is aimed to determine the seabass angling with set lines which is not performed intensively by local fishermen and can be considered as a new and efficient method in the central Aegean Sea.

\section{MATERIALS AND METHOD}

Study was conducted between June and September 2008 in Dalyanköy, Çeşme (Figure 1). Samplings were carried out by PE material boat (3.75 m length, 9.9 HP engine). Technical plan of the fishing set used in the experiments is given in Figure 2.

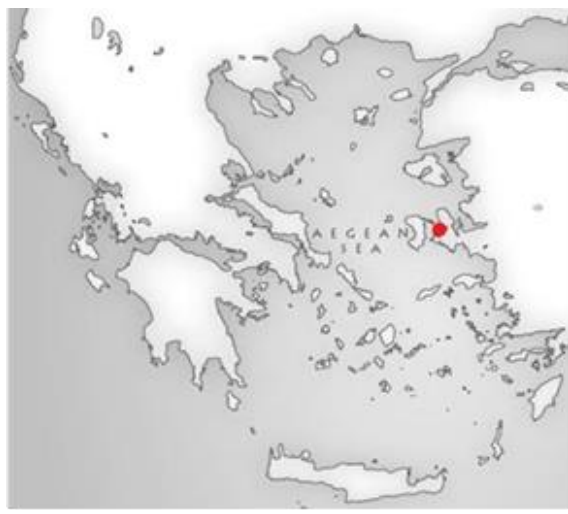

Figure 1. Study area
A total of 213 experiments were performed in 24 trials at depths of 2-10 m during the study. Annular sea bream (Diplodus annularis) and flathead grey mullet (Mugil cephalus) were used as live baits while picarel (Spicara $s p$.) and elegant cuttlefish (Sepia elegans) were used as dead baits which of all four species have been traditionally used in this fishery in the mentioned area. Furthermore live baits and the picarels were collected by hand lines and traps and the elegant cuttlefish samples were obtained from discarded part of the commercial trawling. Regarding the experiments, 80 hooks were baited with annular sea bream, 60 of them were baited with flathead grey mullet and finally 43 and 30 of them were baited with picarel and elegant cuttlefish respectively. Baits except the elegant cuttlefish were fitted to hooks called as "the sewing method" by the local fishermen. Total and mantle lengths of baits are given in Table 1.

Table 1. Lengths of the baits.

\begin{tabular}{lcccccc} 
& $\mathbf{n}$ & LT & min & max & mean & std.err. \\
\cline { 2 - 7 } Annular sea bream & 80 & $\mathrm{TL}$ & 7,0 & 10,0 & 8,2 & 0,1 \\
Flathead grey mullet & 60 & $\mathrm{TL}$ & 10,0 & 16,0 & 13,6 & 0,2 \\
Picarel & 43 & $\mathrm{TL}$ & 7,2 & 11,2 & 8,9 & 0,1 \\
Elegant cuttlefish & 30 & $\mathrm{ML}$ & 2,2 & 6,2 & 3,9 & 0,1 \\
\hline
\end{tabular}

*LT:Length type, TL:Total length, ML:Mantle length

Baited set lines were left to the water during the sunset and taken back in the following day during the sun rise corresponding 10 hours of fishing time. Results were recorded on boat and the total length (TL) of captured individuals was measured to the nearest $0.1 \mathrm{~cm}$ using a $100 \mathrm{~cm}$ ruler, while the weight $(\mathrm{W})$ of them were taken by a digital balance with a precision of $10 \mathrm{gr}$. Data were evaluated by the MS office Excel 2007 and Statistica 7.0 software. Furthermore the effect of 2 baits, flathead grey mullet and annular sea bream, on the length of seabass individuals was examined with analysis of variance (one way anova).

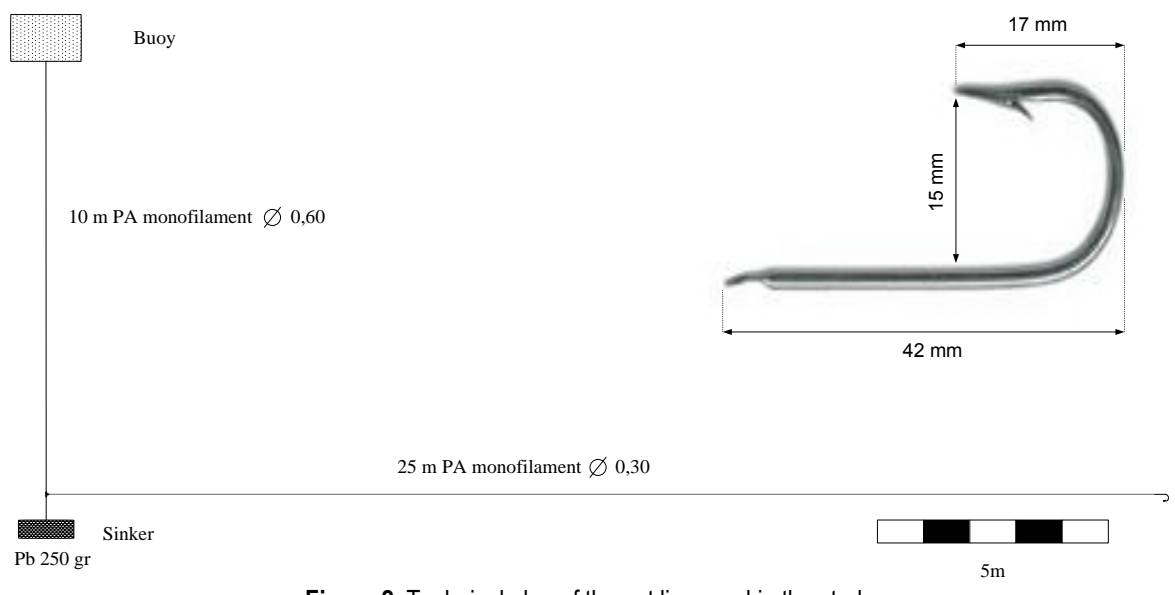

Figure 2. Technical plan of the set line used in the study 


\section{RESULTS}

A total of 213 fishing operations were carried out. As a result of those, 60 individulas belonging to 3 species; seabass (Dicentrarchus labrax), (38915.5 gr, $\mathrm{n}=40)$, European conger (Conger conger) (9280 gr, $\mathrm{n}=19$ ) and common smooth hound (Mustelus mustelus) (770 gr, $\mathrm{n}=1$ ) were captured. Weight based distribution of the catch composition is shown in Figure 3. Nevertheless it was found that 57 angles were detached from anywhere on the snood and 96 of the attempts did not catch any fish. Moreover 29 of them were observed with the bait on the hook after the catch period but 67 of them were baitless among these 96 experiments. It was determined that the baitless setlines were baited with picarel and elegant cuttlefish (Figure 4).

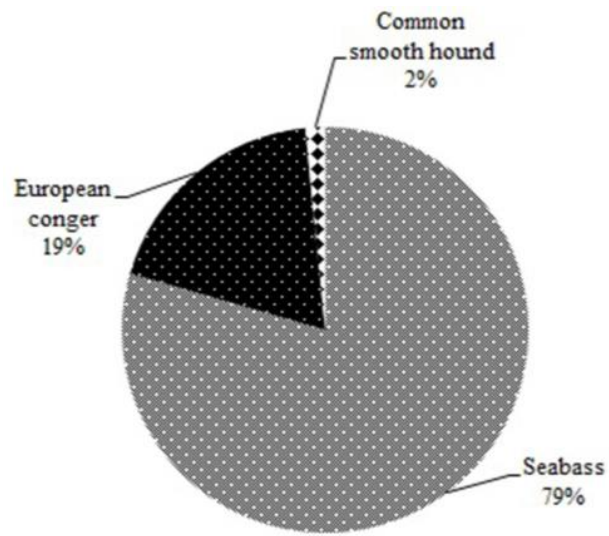

Figure 3. Weight based distribution of the catch composition

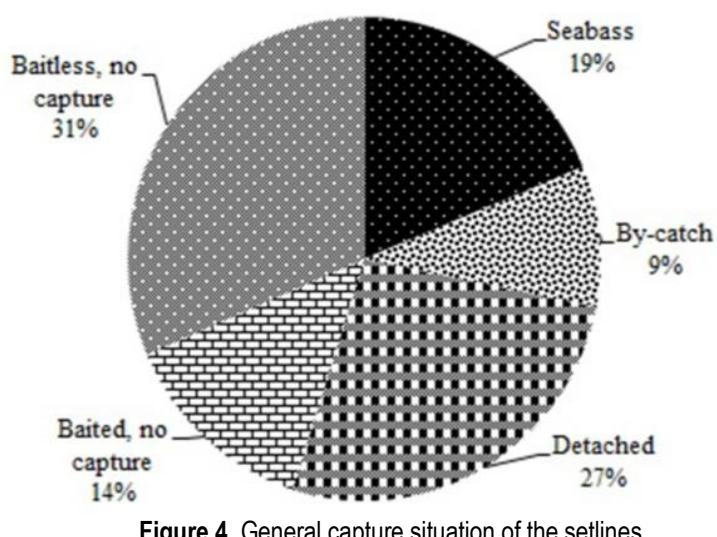

It was determined that catch efficiencies of the tackles differed according to different baits. The target species of the study, European seabass was mostly captured by flathead grey mullet and the data regarding to other species are given in Figure $5.35 .4 \mathrm{~cm}$ and $69.5 \mathrm{~cm}$ total lengths belonged to the minimum and maximum sizes of sea bass captured by flathead grey mullet while $31.8 \mathrm{~cm}$ and $58.6 \mathrm{~cm}$ sizes were determined for the set lines baited with annular sea bream. According to bait type, weight distribution of 40 seabasses is shown in Figure 6 . Furthermore the greatest and the smallest seabass individuals were captured with flathead grey mullet and annular sea bream respectively. Another finding regarding the European conger is that the majority of the individuals and the greatest one were captured with annular sea bream. In addition, the only one common smooth hound which was 63 $\mathrm{cm}$ in total length and weighed $770 \mathrm{gr}$ was also tackled with annular sea bream during the study.

Mean lengths of captured species depending on the bait type are given in Table 2. Nevertheless the difference between the lengths of European seabass belonging to different baits, flathead grey mullet and annular sea bream was found statistically insignificant ( $p>0.05)$.

Table 2. Mean lengths and weights of captured species related to bait type

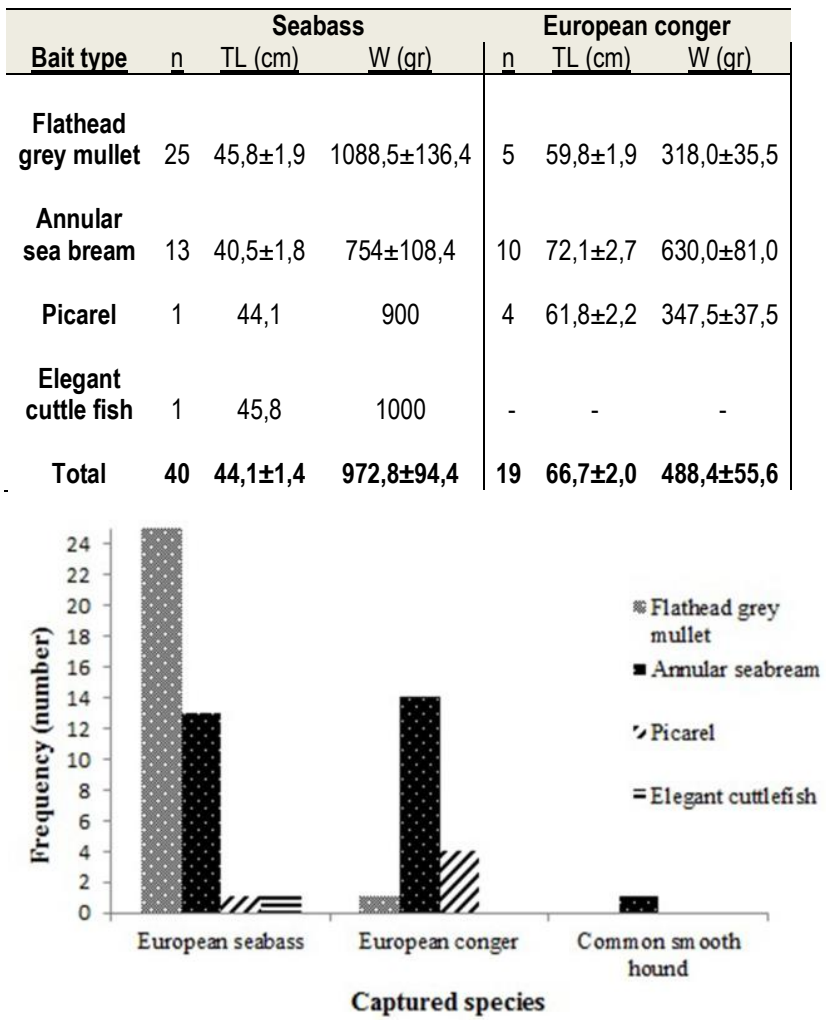

Figure 5. Catch composition of the baits

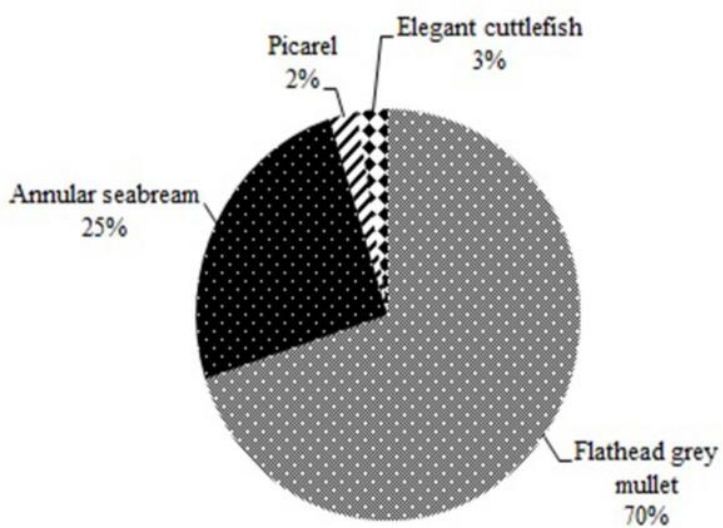

Figure 6. Weight distribution of European seabass according to bait type 


\section{DISCUSSION}

In recent years hand lining has become very popular especially for recreational fishing. Dilon (2004) reported the number of anglers for 2002 as 2 million in United Kingdom while 361.000 people were assessed to fish only for European seabass in 1992. Nevertheless the author also added that 18.300.000 £ was spent by European seabass fishermen in 1992 and $28 \%$ of this cost belonged to on boat bass angling. Furthermore there has been no data for Turkey regarding the subjects mentioned above.

As a result of 213 setlining experiments, 60 individuals belonging to 3 species which totally weight 48965.5 gr were obtained. Fishing for European seabass as having high commercial value has been conducted by gill nets, longlines, fish weirs, spears and fishing lines (angling) in Turkish coasts. Nevertheless, scientific studies on European seabass angling are scarce. Pasiner (1998) reported 5 methods for bass angling which are bottom trolling, natural baited handline, artificial baited handline, vertical longline and setline. Despite bass angling has been performed by on shore fishery, this method has been applied by local fishermen for long time in the study area. Technical features, catch composition and the baits of this technique were determined for the first time in this study for Turkey. Flathead grey mullet has been found as the most efficient bait and followed by annular sea bream. Furthermore tackles baited with picarel and the elegant cuttlefish captured less bass in comparison to live baited setlines. European sea bass has been reported as a predator species and the predation of adult individuals focused on fish (Kottelat and Freyhof, 2007). This situation shows that results of our study are compatible with the findings of the authors. In addition to this, mean length of all bass individuals was calculated as $44.1 \pm 1.4 \mathrm{~cm}$ and this length is above the minimum landing size (MLS) for Turkey which has been declared as $25 \mathrm{~cm}$ (Anonymous 2012). Eaton (1996) clarified the MLS as $36 \mathrm{~cm}$ total length in the covering waters from north of Shetlands to the Straits of Gibraltar. Nevertheless information taken from Central Fisheries Board website of Republic of Ireland declared the MLS as $40 \mathrm{~cm}$ and only 2 basses are allowed to capture per day. In addition sexual maturity length of European sea bass has been reported as 20 and $29 \mathrm{~cm}$ (TL) for males and females respectively (Wassef ve El Emary, 1989) in the Mediterranean. It was observed that all seabass individuals obtained from the present study are above the mentioned sizes. Therefore, bass setlining is considered to be a size selective method by capturing individuals above the minimum reproduction length. Furthermore catch composition also indicated the selectivity at species level. According to the findings it was determined that $69 \%$ of the total catch was targeted. Another case regarding the catch composition is discarding of European congers by local fishermen in the study area. Nevertheless Soykan (2011), reported commercial evaluation of European congers from bottom trawl fishery in Middle Aegean Sea. It is assumed that discard ratio of this fishery can decrease by adding the European congers into the commercial part of the catch composition if it is possible to market.

Another situation related to operations was more than $1 / 4$ of the tackles detached from anywhere on the snood. While some of those had a very clear detachment like an incision, the others seemed to detach by damaging or bruising of the snood. Clear detachments of the snoods may belong to sharp operculum movement of a bass or an outside agent (screw, human activity, etc.) and the damaged detachments are assumed to happen because of the movement of live bait or any captured individual according to observations and interviews with experienced anglers. They are considered to be entangled to the rocks or hard structures at the bottom during their reaction after being caught or baited. This case was supported by Pasiner (1998). He stated the behaviour of European seabass after being captured as moving the line into its operculum and cuts it like a blade.

The present work, as being the first about setlining for European seabass, investigated the basic features of this method in Çeşme Peninsula, central Aegean Sea. According to obtaining results, setlining for European seabass can be considered as a cheap and efficient way of capture and it is not a very common technique compared to other sea bass capturing methods. This tackle which targets the European sea bass, a high commercial species, is considered to be sustainable regarding the sizes of individuals and the by-catch characteristics. On the other side, more reliable results can be obtained by increasing the number of samplings concerning the catch composition and bait preference of seabass. Therefore more detailed studies are required on the behaviour, bait preference and the fishery of the species. Recently, catch pressure on European seabass has been increasing with commercial and recreational purposes equipped with high technology gears. Hereby seabass populations locating in the Turkish coasts should be determined and all fishing methods for the species should be managed under scientific criteria.

\section{ACKNOWLEDGEMENT}

We would like to thank Efdal GENCER for his assistance in setlining experiments and data gathering.

\section{REFERENCES}

Akyol, A., Ceyhan, T., Ertosluk, O., 2009. Coastal fisheries and fishing resources of Marmara Island (in Turkish with English abstract), Ege Journal of Fisheries and Aquatic Sciences, 26(2): 143-148.
Anonymous, 2012. Fisheries regulation for marine and fresh waters for commercial fishery, 2008-2012 fishing period No: 2/1, Ministry of Agriculture and Rural Affair of Turkey, Protect and Control General Office, Ankara, p. 85. (in Turkish) 
Aydın, I.., 2011. Is natural bait type a stochastic process for size and condition of fishes in the recreational fishery of Izmir Bay?, Mediterranean Marine Science, 12(2): 390-400. doi:10.12681/mms.39

Ceyhan, T., Akyol, O., 2005. The hand lines, used in bluefish (Pomatomus saltatrix L., 1766) fishery in Marmara Region (in Turkish with English abstract), Ege Journal of Fisheries and Aquatic Sciences, 22(3-4): 351 355

Dillon B., 2004. A bio-economic review of recreational angling for Bass (Dicentrachus labrax). Scarborough Centre for Coastal Studies, University of Hull.

Eaton, D.R., 1996. The identification and Separation of wild caught and cultivated sea bass (Dicentrarchurus labrax). Fisheries Research Technical Report no. 103, Directorate of Fisheries Research, Lowestoft.p.5.

EAA (European Anglers Alliance), 2003. Press Release form the European Anglers Alliance (n.d), Europe's 25 million anglers demand equal rights to commercial fishermen. Retrieved June 152012 from http://www.eaaeurope.org/fileadmin/templates/eaa/docs/EAA_News_Jan_2003_EN \%20Correct.pdf

FAO,2010.http://www.fao.org/figis/servlet/SQServlet?file=/usr/local/tomcat/FI/ 5.5.23/figis/webapps/figis/temp/hqp_6014.xml\&outtype=html.

Frimodt, C., 1995. Multilingual illustrated guide to the world's commercial warmwater fish. Fishing News Books, Osney Mead, Oxford, England.
Hoşsucu, H., 2003. Fishing I (in Turkish). Ege University Faculty of Fisheries Publications No: 55, Lecture Book Index No: 24. E.U. Printery, Bornova, İzmir.

Kaykaç, H., Ulaş, A., Metin, C., Tosunoğlu, Z., 2003. A study on catch efficiency of straight and kirbed hooks at hand line fishing (in Turkish with English abstract), Ege Journal of Fisheries and Aquatic Sciences, 20(12): 227-231.

Kottelat, M. Freyhof, J., 2007. Handbook of European freshwater fishes. Publications Kottelat, Cornol, Switzerland.

Pasiner, A., 1998. Fish and hand line (in Turkish). Remzi Kitabevi, Cağaloğlu, İstanbul.

Soykan, O., 2011. Seasonal distribution of by-catch species in Sığacık Bay by demersal trawl (in Turkish with English Abstract), Ph.D. thesis, Ege University, Graduate School of Natural and Applied Sciences, 111p.

TUIK (Turkish Statistical Institute), 2010. Fishery statistics 2010, Ankara

Ünal, V., 2003. Socio-economic analysis of part time small-scale fishery, Foça (Aegean Sea) (in Turkish with English Abstract), Ege Journal of Fisheries and Aquatic Sciences, 20(1-2): 165-172.

Wassef, E., El Emary, H., 1989. Contribution to the biology of bass, Dicentrarchus labrax L. in the Egyptian Mediterranean waters off Alexandria, Cybium, 13(4): 327-345. 